\title{
Encefalopatia septyczna a majaczenie stanu ciężkiego
}

\section{Sepsis-associated encephalopathy and ICU delirium}

\author{
Katarzyna Kotfis ${ }^{凶}$
}

Pomorski Uniwersytet Medyczny w Szczecinie, Klinika Anestezjologii, Intensywnej Terapii i Ostrych Zatruć, al. Powstańców Wlkp. 72, 70-111 Szczecin Pomeranian Medical University in Szczecin, Department of Anaesthesiology, Intensive Care and Acute Poisoning $\triangle$ katarzyna.kotfis@pum.edu.pl

\begin{abstract}
Introduction: Sepsis-associated encephalopathy is an acute dysfunction of the central nervous system (CNS) that arises as a consequence of generalized systemic infection, yet without brain infection.

The aim of this review is to introduce septic encephalopathy as a disease, with all of the epidemiology data, diagnostic opportunities, pathophysiology and possible treatment.

Sepsis-associated encephalopathy is a medical condition characterized by a broad spectrum of disturbances of consciousness, from delirium to coma, with possible seizures or focal neurological signs. Many pathophysiological mechanisms lie at the basis of septic encephalopathy, including inflammation or dysfunction of cerebral perfusion. Another important mechanism includes interactions between inflammatory cytokines and acetylcholine that lead to abnormal cholinergic transmission and neuronal death. Moreover, interaction between acetylcholine and inflammatory cy tokines may induce immunosuppression. Sepsis-associated encephalopathy diagnosis is strictly clinical, based on neurological examination and the exclusion of other causes, because there are no definite biochemical tests or radiological studies specific for this disease. The use of ICU delirium screening tools, such as CAM-ICU (Confusion Assessment Method for the Intensive Care Unit) enables earlier detection of brain dysfunction. Neuroimaging studies (computed tomography,
\end{abstract}

magnetic resonance imaging), as well as electroencephalograhy may be helpful in the assessment of the severity of dysfunction. The most important element is early diagnosis of sepsis, especially with the use of the QuickSOFA scale, and early initiation of multidirectional treatment according to Surviving Sepsis Campaign guidelines: early source identification and source control, initiation of optimal antibiotic therapy, adequate fluid therapy and supportive treatment for major organs. In order to prevent CNS dysfunction in the ICU, deep sedation and benzodiazepines should be avoided and dexmedetomidine and propofol introduced instead. Pharmacological treatment of ICU delirium is based on the use of typical (haloperidol) and atypical (i.e. quetiapine) antipsychotics. Non-pharmacological methods include early mobilization, ensuring day and night cycles, the minimalization of noctural factors (light, sounds, interventions), and family engagement.

Conclusion: Sepsis-associated encephalopathy is a serious illness associated with severe consequences, including increased mortality, long-term cognitive dysfunction, and immunosuppression. The co-dependence between septic encephalopathy and the immune system should be underlined in the approach towards sepsis treatment.

Keywords: sepsis associated encephalopathy; sepsis; ICU delirium; CAM-ICU; cognitive dysfunction.

\begin{abstract}
ABSTRAKT
Wstęp: Encefalopatia septyczna (sepsis-associated encephalopathy - SAE) jest ostrym zaburzeniem funkcjonowania ośrodkowego układu nerwowego (OUN), które pojawia się w następstwie infekcji ogólnoustrojowej, jednak bez infekcji samego mózgu. Celem niniejszego opracowania było przedstawienie encefalopatii septycznej jako jednostki chorobowej, z uwzględnieniem danych epidemiologicznych, diagnostycznych i patofizjologii oraz możliwości leczenia.

Stan ten charakteryzuje się szerokim spektrum zaburzeń świadomości od majaczenia aż do śpiączki oraz możliwością wystąpienia drgawek czy ogniskowych objawów neurologicznych. U podłoża encefalopatii septycznej leży wiele mechanizmów patofizjologicznych, takich jak zmiany zapalne czy zaburzenia regulacji przepływu mózgowego. Niezwykle istotne są interakcje pomiędzy krążącymi cytokinami zapalnymi a acetylocholiną, co prowadzi do zaburzeń przekaźnictwa cholinergicznego i obumierania neuronów. Dodatkowo interakcja pomiędzy acetylocholiną a cytokinami zapalnymi może indukować stan immunosupresji.
\end{abstract}

Rozpoznanie SAE jest ściśle kliniczne, stawiane na podstawie badania neurologicznego i wykluczenia innych przyczyn, ponieważ nie istnieją zdefiniowane testy biochemiczne czy badania obrazowe specyficzne dla tego schorzenia. Zastosowanie metod rozpoznawania majaczenia na oddziałach intensywnej terapii (OIT), takich jak CAM-ICU (Confusion Assessment Method for the Intensive Care Unit), pozwala na wcześniejsze wykrycie zaburzeń mózgowych. Badania neuroobrazowe (tomografia komputerowa, obrazowanie metodą rezonansu magnetycznego mózgowia), jak również elektroencefalografia mogą być pomocne w ocenie ciężkości zaburzeń.

Najważniejszym elementem leczenia jest wczesne rozpoznanie sepsy, zwłaszcza poprzez stosowanie skali QuickSOFA, oraz wczesne wdrożenie wielokierunkowego leczenia sepsy zgodnie z wytycznymi Surviving Sepsis Campaign, co obejmuje przede wszystkim: wczesną identyfikację i kontrolę źródła zakażenia, wdrożenie optymalnej antybiotykoterapii, prowadzenie adekwatnej płynoterapii i podtrzymanie funkcji poszczególnych narządów. Sposobem zapobiegania zaburzeniom OUN na OIT 
jest unikanie głębokiej sedacji oraz unikanie benzodiazepin na korzyść deksmedetomidyny i propofolu. W postępowaniu farmakologicznym podczas leczenia majaczenia zalecane jest stosowanie typowych (haloperidol) i atypowych (kwetiapina) leków przeciwpsychotycznych. Metody niefarmakologiczne obejmują wczesne uruchomienie pacjentów, zapewnienie cyklu dzień-noc, minimalizację bodźców w godzinach nocnych (światło, dźwięki, interwencje) oraz zaangażowanie rodziny do opieki nad chorym.
Podsumowanie: Encefalopatia septyczna jest zaburzeniem obarczonym ciężkimi powikłaniami, takimi jak zwiększona śmiertelność, długoterminowe zaburzenia poznawcze czy postępująca immunosupresja. Wzajemna zależność pomiędzy encefalopatią septyczną a wieloma narządami obwodowymi i układem odpornościowym powinna znaleźć odzwierciedlenie w podejściu do leczenia sepsy.

Słowa kluczowe: encefalopatia septyczna; sepsa; majaczenie; delirium ICU; CAM-ICU; zaburzenia poznawcze.

\section{WSTĘP}

U wielu pacjentów z ciężką uogólnioną infekcją niejednokrotnie dochodzi do zaburzeń funkcji mózgu, które występują bez oczywistego wyjaśnienia i uchwytnej jednoznacznej przyczyny, przez co stanowią poważny problem diagnostyczny i terapeutyczny [1]. Po wykluczeniu wielu możliwych przyczyn zaburzeń funkcjonowania ośrodkowego układu nerwowego (OUN) w przebiegu ciężkiej infekcji jedynym możliwym rozpoznaniem jest encefalopatia septyczna (sepsis-associated encephalopathy-SAE), czyli ostre zaburzenie funkcjonowania mózgu pojawiające się w następstwie infekcji ogólnoustrojowej, jednak przebiegające bez infekcji samego mózgu [2, 3].

Celem niniejszego opracowania było omówienie tej złożonej jednostki chorobowej z uwzględnieniem danych epidemiologicznych, diagnostycznych, patofizjologii oraz możliwości leczenia.

\section{DEFINICJE}

Szerokie spektrum zaburzeń funkcjonowania OUN w sepsie obejmuje wiele pojęć. W literaturze anglosaskiej pojawiło się określenie ostrej dysfunkcji mózgowia związanej z sepsą, do którego należy encefalopatia związana z sepsą SAE oraz delirium związane z sepsą (sepsis associated delirium - SAD) [1].

Encefalopatia związana z sepsą to najszerzej opisana jednostka chorobowa, która obejmuje zaburzenia funkcjonowania mózgowia, wtórne do uogólnionej infekcji organizmu, jednak bez obecności wyraźnej infekcji w obrębie mózgowia. Schorzenie to dotyczy pełnego spektrum objawów neurologicznych, takich jak: majaczenie, śpiączka, drgawki, ogniskowe ubytki neurologiczne oraz zmiany w zachowaniu, jak również zaburzenia poznawcze, świadomości i przytomności. W aktualnych podręcznikach diagnostycznych DSM-5 i International Classification of Diseases (ICD-10) termin „encefalopatia septyczna” zastępowany jest stopniowo przez termin „majaczenie septyczne". Należy podkreślić, że spektrum septycznych zaburzeń OUN cechuje pewna chronologia, przy czym encefalopatia może wyprzedzać inne objawy sepsy.

\section{EPIDEMIOLOGIA}

Szacuje się, że encefalopatia septyczna jest najczęstszą przyczyną majaczenia w stanach nagłych i dotyka 8-70\% pacjentów z uogólnioną infekcją [4]. Sepsa jest najczęstszą przyczyną przyjęć na oddziały intensywnej terapii (OIT), natomiast SAE/ SAD to bardzo często spotykane patologie u ciężko chorych pacjentów. Należy pamiętać, że wdrożenie sedacji i analgezji, niezbędne dla zapewnienia pacjentowi komfortu, zaburza obraz neurologiczny, co utrudnia rozpoznanie majaczenia u pacjentów z sepsą. Częstość encefalopatii jest wyższa u pacjentów z bakteriemią i cechami niewydolności nerek, niewydolności wątroby lub niewydolności wielonarządowej. Szacuje się, że aż 70\% pacjentów z bakteriemią prezentuje objawy zaburzeń świadomości od senności do śpiączki, przy czym 80\% z tych pacjentów ma zmiany w elektroencefalografii (EEG). Niezwykle istotny jest fakt, że pacjenci leczeni na OIT (niezależnie od jego profilu), u których zdiagnozowane zostaną majaczenia związane ze stanem ciężkim, są zagrożeni ryzykiem wystąpienia długoterminowych zaburzeń poznawczych [5].

Badania Zhang i wsp. pozwoliły zidentyfikować czynniki ryzyka dla tego schorzenia przy przyjęciu na OIT, dlatego wiadomo, że pacjenci SAE podczas przyjmowania na OIT w stosunku do pacjentów bez tej patologii mają: wyższą punktację w skali APACHE II, wyższą częstość rytmu serca, wyższy poziom mleczanów czy natremię osoczową, a z drugiej strony niższą punktację w skali Glasgow Coma Scale, niższy poziom płytek krwi, niższe stężenie albumin oraz pH poniżej normy [6].

Pojawienie się encefalopatii septycznej podczas leczenia na OIT niesie za sobą długofalowe konsekwencje. Ostatnie badania wskazują, że pacjenci z ostrym uszkodzeniem płuc, u których testy neuropsychologiczne przeprowadzono 2 i 12 miesięcy po wypisie ze szpitala, cierpieli z powodu zaburzeń pamięci (13\%), płynności słownej (16\%), funkcji wykonawczych (49\%) i zaburzeń poznawczych (55\%). Istotne problemy dotykające osoby, które przeżyły ciężką chorobę i zostały wypisane z OIT, to depresja (36\%), zespół stresu przewlekłego (39\%) oraz zaburzenia lękowe (62\%) [7].

Uwagę zwraca fakt, że wielu pacjentów na OIT z niewydolnością oddechową lub wstrząsem wykazuje zaburzenia poznawcze i majaczenie, co może dotyczyć nawet $74 \%$ pacjentów hospitalizowanych na OIT. Trzy miesiące po wypisie z oddziału aż 40\% osób wykazuje w badaniach neuropsychologicznych cechy podobne do tych, jakie występują po urazie mózgowia, a 26\% ma wyniki podobne do łagodnej choroby Alzheimera [8]. W kohorcie starszych pacjentów bez demencji, hospitalizowanych z powodu ciężkiej choroby, wykazano większe zaburzenia poznawcze po wypisie z OIT niż przed przyjęciem [9]. 


\section{PATOFIZJOLOGIA}

Zaburzenia homeostazy OUN, które leżą u podłoża SAE, obejmują szereg przenikających się wzajemnie elementów (ryc. 1). Zmiany te obejmują:

- zaburzenia przekaźnictwa mózgowego,

- aktywację mikrogleju,

- aktywację komórek śródbłonka,

- dysfunkcję bariery krew-mózg,

- deficyt przekaźnictwa cholinergicznego i zmiany neurotransmisji,

- stres oksydacyjny, dysfunkcję mitochondriów i apoptozę neuronów OUN [10].

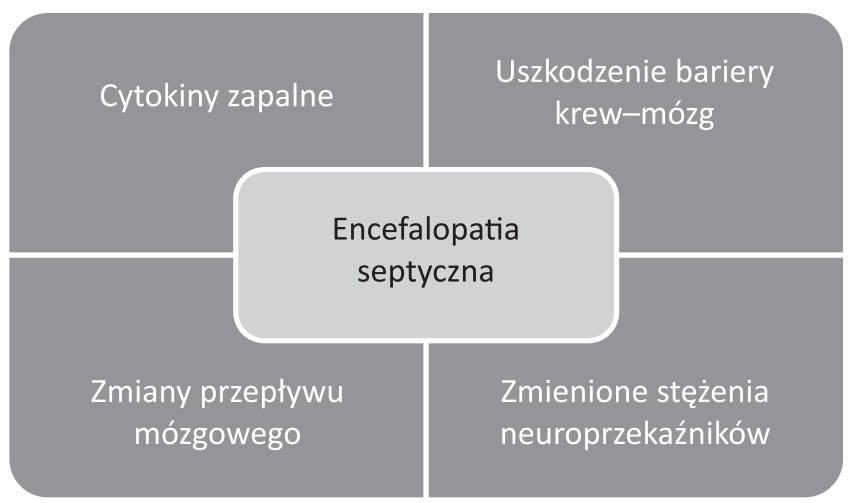

RYCINA 1. Schemat zależności grup zaburzeń patofizjologicznych w rozwoju encefalopatii septycznej

Zmiany patofizjologiczne w SAE są bardzo złożone, a szczegółowe ich omówienie przekracza ramy niniejszego opracowania. Należy jednak podkreślić fakt, że w schorzeniu tym biorą udział dwa przenikające się mechanizmy:

1. Niedokrwienie - upośledzenie makrokrążenia z równoczesną dysfunkcją mikrokrążenia oraz rozsiane wykrzepianie wewnątrznaczyniowe (DIC) w następstwie aktywacji komórek śródbłonka.

2. Zapalenie tkanki nerwowej - dysfunkcja kompleksu neuronaczyniowego (śródbłonek - bariera krew-mózg - astrocyty), co umożliwia pasaż mediatorów zapalnych i czynników neurotoksycznych z krwi do mózgu.

W efekcie przenikania się tych procesów dochodzi do aktywacji mikrogleju, co nasila zmiany zapalne. Z kolei aktywacja mikrogleju i zaburzenia funkcjonowania astrocytów prowadzą do dysfunkcji lub obumarcia neuronów [11]. Proces ten powoduje występowanie objawów klinicznych i odpowiada za długofalowe zaburzenia występujące już po wyleczeniu chorego i po wypisie z OIT [12].

\section{ROZPOZNANIE ENCEFALOPATII ZWIĄZANEJ Z SEPSĄ}

\section{Rozpoznanie kliniczne}

Rozpoznanie SAE jest ściśle kliniczne i powinno być stawiane na podstawie badania neurologicznego i wykluczenia innych przyczyn, ponieważ nie istnieją testy biochemiczne czy badania obrazowe w pełni specyficzne dla tego schorzenia. Objawy mogą sięgać od łagodnego majaczenia do głębokiej śpiączki; niejednokrotnie występują zaburzenia cyklu snu i czuwania, pobudzenie, niepokój, halucynacje. Dodatkowo prawie 70\% przypadków ciężkiej encefalopatii septycznej współistnieje z neuropatią i miopatią związanymi z ciężką chorobą (critical illness associated neuromyopathy).

Zastosowanie metod przesiewowych do rozpoznawania majaczenia na OIT, takich jak CAM-ICU (Confusion Assessment Method for the Intensive Care Unit), pozwala na wcześniejsze wykrycie zaburzeń. Badania neuroobrazowe, takie jak tomografia komputerowa (TK) czy obrazowanie metodą rezonansu magnetycznego (MRI) mózgowia, jak również badania elektrofizjologiczne, takie jak EEG czy ocena czuciowych potencjałów wywołanych (sensory evoked potentials - SEP), mogą być pomocne w ocenie ciężkości zaburzeń.

\section{Neuroobrazowanie}

Wykonanie obrazowania mózgowia metodą TK jest wskazane u pacjenta z sepsą zawsze wtedy, gdy dochodzi do zmiany stanu, tj. nagle pojawia się pobudzenie, śpiączka czy delirium, których nie da się wytłumaczyć stosowanymi lekami sedatywnymi. Neuroobrazowanie mózgowia w SAE wskazuje na zaawansowane zaburzenia istoty białej, atrofię, okołokomorowe zmiany istoty białej oraz zmiany o charakterze obrzęku mózgu. Tomografia komputerowa mózgowia jest przydatna w diagnostyce różnicowej dużych zmian, takich jak ubytki ogniskowe, krwawienie do OUN czy zmiany niedokrwienne. Z kolei badanie rezonansu magnetycznego (MR) mózgowia daje wczesne i dokładne informacje na temat uszkodzenia istoty białej i bariery krew-mózg, a jednocześnie wykazuje subtelne zmiany, takie jak mikroudary niedokrwienne czy leukoencefalopatię, jednak nie zawsze jest ono możliwe do wykonania w warunkach oddziału intensywnej terapii [13].

\section{Elektroencefalografia}

Wykonanie badania elektrofizjologicznego powinno się rozważyć u wszystkich pacjentów w stanie septycznym, u których występuje śpiączka lub przedłużające się delirium pomimo poprawy funkcji narządów i wyeliminowania leków sedatywnych i ich metabolitów. Badanie EEG może być pomocne, gdy trzeba wykluczyć nienapadowy stan padaczkowy u krytycznie chorego pacjenta [14].

Z kolei badanie SEP może być istotnym wskaźnikiem encefalopatii indukowanej przez sepsę, choć jest trudne i czasochłonne, a stosowane raczej w badaniach klinicznych. Jednak zdecydowana przewagą SEP jest fakt, że sedacja (bolusy, wlew dożylny) nie wpływa na przebieg ani wynik badania. Young i wsp. na grupie 69 septycznych pacjentów, z których 49 prezentowało encefalopatię, wyróżnili 5 klas pogarszającego się wzoru EEG obciążającego rokowniczo:

1. Prawidłowy zapis EEG - 0\% śmiertelność.

2. Nadmiar fal theta $-19 \%$ śmiertelność.

3. Dominujące fale delta $-36 \%$ śmiertelność.

4. Fale trójfazowe $-50 \%$ śmiertelność. 
5. Wytłumienie zapisu (suppression czy burst suppression) $67 \%$ śmiertelność [15].

Badanie elektrofizjologiczne ma wysoką czułość dla SAE i wykazuje patologię nawet wówczas, gdy badanie neurologiczne jest bez odchyleń, jednak posiada ograniczoną specyficzność, ponieważ inne rodzaje encefalopatii, w tym wątrobowa i mocznicowa, prezentują podobny obraz kliniczny i mogą się na siebie nakładać.

\section{Biomarkery}

W rozpoznaniu SAE nie ma testów jednoznacznie diagnostycznych dla tej choroby, jednak obowiązuje minimum badań, które należy wykonać, aby wykluczyć inne choroby, w tym: morfologię, poziom elektrolitów, mocznik, kreatyninę, białko C-reaktywne czy prokalcytoninę. W rozpoznaniu SAD stosuje się skale majaczenia dedykowane dla intensywnej terapii, które mogą wskazywać na patologię w zakresie OUN jeszcze przed rozpoznaniem sepsy $[16,17]$.

W chwili obecnej żaden z biomarkerów zaburzenia funkcjonowania OUN nie został określony jako specyficzny dla encefalopatii septycznej, jednak poziom NSE (enolazy specyficznej dla neuronów), białka S100 $\beta$ czy GFAP (glial fibrillary acidic protein) w surowicy może odzwierciedlać uszkodzenie OUN [18]. W grupie 170 pacjentów z sepsą 42\% miało podwyższony poziom białka S100 $\beta$ w surowicy, a u 53\% w ciągu 72 godz. od przyjęcia podwyższony był poziom NSE [16]. Badanie przeprowadzone przez van den Boogaard i wsp. wykazało, że zwiększenie poziomu IL-8 w osoczu było związane z majaczeniem u pacjentów septycznych, podczas gdy u osób z majaczeniem, ale bez stanu zapalnego, podwyższone były poziomy IL-10 i beta-amyloidu $\beta$ [16]. Co więcej, pacjenci z majaczeniem w stanie zapalnym, u których później wystąpiły zaburzenia poznawcze, mieli podwyższony poziom amyloidu beta [19]. Mając na względzie zdecydowanie zapalny charakter uszkodzenia OUN w sepsie, brak jednoznacznych, czułych i specyficznych markerów uszkodzenia OUN utrudnia rozpoznanie, dlatego konieczne jest stworzenie panelu biomarkerów diagnostycznych dla encefalopatii septycznej.

\section{POWIKŁANIA}

\section{Zwiększenie śmiertelności}

Wnioskiem wielu badań obserwacyjnych u pacjentów OIT w podeszłym wieku jest związek między wystąpieniem majaczenia a ryzykiem zgonu, przewlekłą hospitalizacją czy wystąpieniem demencji. Jest to niezależne od wieku, płci, chorób współistniejących lub wcześniejszego rozpoznania otępienia. Śmiertelność u tych pacjentów wynika nie tyle z zaburzeń neurologicznych, ile z niewydolności wielonarządowej [6]. W rzeczywistości wykazano, że stwierdzenie majaczenia wyprzedzało rozpoznanie sepsy u ponad 30\% osób [20].

\section{Zaburzenia poznawcze}

Niezbite dowody, zarówno z badań na zwierzętach, jak i z badań na ludziach, wskazują, że poważne zaburzenia poznawcze są bezpośrednio związane z SAE. Badania na zwierzętach wykazują długoterminowe zaburzenia zachowania, uczenia się i pamięci po encefalopatii septycznej. Przedłużający się czas trwania majaczenia jest niezależnym czynnikiem ryzyka dla zaburzeń poznawczych oraz funkcji wykonawczych po 3 i 12 miesiącach od rozpoznania [5, 21]. Dodatkowo dłuższy czas trwania majaczenia jest związany ze zmniejszeniem objętości mózgowia 3 miesiące po wypisie z OIT, a to z kolei związane jest z długoterminowymi zaburzeniami poznawczymi aż do 12 miesięcy po wypisie [22].

\section{Postępująca immunosupresja}

Encefalopatia septyczna może prowadzić do postępującej immunosupresji, co związane jest z aktywacją współczulnego układu nerwowego oraz częściowo wynika z aktywacji osi nadnercza-przysadka-podwzgórze, co w konsekwencji prowadzi do utraty kontroli organizmu nad przebiegiem infekcji. Encefalopatia septyczna staje się elementem błędnego koła w infekcji. Dodatkowo późniejsze stadia sepsy mogą być związane z immunosupresją szeroko definiowaną jako limfopenia, dysfunkcja monocytów, zaburzenia ekspresji antygenów HLA-DR (human leukocyte antigen) oraz zwiększonego poziomu IL-10 w osoczu [23, 24].

Bezpośrednie dowody wskazują na fakt, że cytokiny prozapalne, takie jak IL-1 $\beta$, mogą indukować zmiany zapalne nie tylko w samym mózgowiu, ale wywołują uogólnioną reakcję przeciwzapalną, bez uogólnionej infekcji [25]. Utrzymywanie się tego stanu może zwiększać ryzyko powikłań infekcyjnych. Dalsze badania kliniczne i eksperymentalne wskazują, że cytokiny prozapalne produkowane przez uszkodzone mózgowie mogą bezpośrednio prowadzić do aktywacji osi nadnerczaprzysadka-podwzgórze oraz pobudzenia współczulnego układu nerwowego [26].

Zmiany neuropatologiczne w SAE są dość podobne do uszkodzenia OUN w przebiegu udaru czy zmian pourazowych, zwłaszcza w zakresie wzrostu poziomu cytokin prozapalnych w OUN. Z czasem aktywacja i dysfunkcja układu immunologicznego w sepsie staje się spiralą nieodwracalnych procesów, które potęgują zmiany neurologiczne, a widoczne są klinicznie pod postacią funkcjonalnego uszkodzenia mózgowia.

\section{Zaburzenia metaboliczne i elektrolitowe}

Niezwykle istotny jest udział OUN w regulacji równowagi metabolicznej i wodno-elektrolitowej, zatem neurologiczne zaburzenia występujące w SAE mogą również prowadzić do opornej na leczenie hiperglikemii oraz hipernatremii [27]. Coraz więcej uwagi poświęca się roli OUN w regulacji wyrzutu i działania insuliny, co przyczynia się do rozwoju częstych chorób metabolicznych, jak cukrzyca i otyłość. Droga czynnika jądrowego kappaB (NF-кB) jest mechanizmem neuronalnym występującym podczas zaburzeń przekaźnictwa w otyłości oraz zaburzeniach działania insuliny, a jednocześnie badania wykazały, że aktywność czynnika NF- $\kappa$ B jest znacznie podwyższona w sepsie [28]. Supresja czynnika IKK $\beta / N F-\kappa B$ chroni przed otyłością i nietolerancją glukozy [29]. 
Występowanie hiperglikemii jest związane z gorszym rokowaniem u pacjentów na OIT, a co więcej - zaburzone przekaźnictwo insulinowe oraz aktywacja czynnika NF-кB mogą być związane z zaburzeniami równowagi metabolicznej i wodno-elektrolitowej w SAE [30, 31]. Zaburzenia równowagi wodnej i elektrolitowej to jedne z najczęściej występujących problemów klinicznych na OIT, dla których nie zawsze znajdowane jest uzasadnienie.

Hipernatremia rozwija się u wielu pacjentów podczas leczenia na OIT, ponieważ wiele czynników promuje utratę czystej wody z organizmu. Niedobór wazopresyny występuje u 1/3 pacjentów w późnych fazach sepsy oraz wstrząsu septycznego i stanowi niezależny czynnik prognostyczny zwiększonej śmiertelności na OIT [32]. Niewykluczone, że SAE może prowadzić do zaburzeń funkcjonowania regionalnego w mózgowiu, zwłaszcza w podwzgórzu i przysadce, które regulują równowagę wodną i elektrolitową.

\section{Interwencje terapeutyczne}

Najważniejszym elementem postępowania terapeutycznego w encefalopatii septycznej jest wczesne rozpoznanie sepsy, zwłaszcza poprzez stosowanie zalecanej aktualnie skali QuickSOFA oraz wczesne wdrożenie leczenia sepsy zgodnie z aktualnymi wytycznymi Surviving Sepsis Campaign [33, 34]. Leczenie sepsy powinno opierać się przede wszystkim na wczesnej identyfikacji i kontroli źródła zakażenia, wdrożeniu optymalnej antybiotykoterapii, prowadzeniu adekwatnej płynoterapii i podtrzymaniu funkcji poszczególnych narządów [34, 35]. Kolejny kluczowy element to eliminowanie czynników nasilających zaburzenia metaboliczne, ograniczanie leków działających na OUN, w tym leków antycholinergicznych, oraz wczesna identyfikacja zespołów odstawiennych (alkohol, benzodiazepiny), które mogą współistnieć i maskować objawy encefalopatii septycznej.

Uznanym sposobem na zapobieganie zaburzeniom OUN jest stosowanie strategii redukcji dysfunkcji mózgu na oddziale intensywnej terapii, do których należą interwencje farmakologiczne i niefarmakologiczne.

\section{Metody farmakologiczne}

W grupie interwencji farmakologicznych wymienić należy:

- stosowanie płytkiej sedacji,

- wprowadzanie codziennych przerw w sedacji,

- unikanie benzodiazepin w sedacji na korzyść propofolu i deksmedetomidyny,

- redukcja zużycia benzodiazepin i opiodów,

- leczenie majaczenia z uwzględnieniem typowych (haloperidol) i atypowych (kwietiapina) leków przeciwpsychotycznych oraz deksmedetomidyny,

- zapobieganie zaburzeniom metabolicznym (ciężka hipoksja, gorączka, ciężka dysnatremia, przedłużająca się hipoksja).

Wobec braku leczenia celowanego dla encefalopatii septycznej możliwe, że przyszłe interwencje będą się koncentrowały na stworzeniu leczenia modulującego aktywację mikrogleju, zapobieganiu zmianom przepuszczalności bariery krew-mózg w OUN czy na stosowaniu antyoksydantów.

\section{Metody niefarmakologiczne}

Metody niefarmakologiczne obejmują następujące interwencje:

- wczesne uruchomienie pacjentów poprzez właściwą,

tj. dostosowaną do funkcjonalnych możliwości fizjoterapię,

- zapewnienie niezaburzonego cyklu dzień-noc poprzez wprowadzenie protokołów snu,

- minimalizacja bodźców w godzinach nocnych (redukcja światła, ograniczenie hałasów, minimalizacja interwencji),

- stosowanie pomocy dla zmysłów: używanie okularów, szkła powiększającego, aparatu słuchowego, protez zębowych,

- bezwzględne unikanie przymusu bezpośredniego,

- zaangażowanie członków rodziny i osób bliskich do opieki nad chorym.

\section{PODSUMOWANIE}

Znaczenie encefalopatii septycznej u pacjentów leczonych na OIT jest w znacznej mierze niedoceniane, a samo schorzenie uważane jest za przemijające po wyleczeniu ciężkiej infekcji. Encefalopatię septyczną powinno się podejrzewać u każdego pacjenta z sepsą, wstrząsem septycznym czy ciężką uogólnioną infekcją, u którego wystąpiła nagła zmiana funkcjonowania OUN.

Obecnie pacjenci z SAE otrzymują jedynie leczenie wspierające funkcję narządów i układów, przy czym podstawą terapii powinno być skuteczne leczenie ciężkiej infekcji (kontrola źródła infekcji i antybiotykoterapia). Brak jest jednak jakichkolwiek interwencji celowanych na poprawę funkcjonowania OUN w sepsie. Niezwykle istotny jest fakt docenienia znaczenia encefalopatii septycznej jako jednostki chorobowej, ponieważ pacjenci, którzy przeżyli epizod sepsy, mają zwiększone ryzyko niepomyślnych konsekwencji, takich jak: osłabienie fizyczne (osłabienie masy mięśni i siły mięśniowej), zaburzenia neurologiczne i poznawcze lub choroby psychiczne po leczeniu na oddziale intensywnej terapii (depresja, zespół przewlekłego stresu pourazowego). Najczęstsze problemy w zakresie zaburzeń poznawczych po hospitalizacji na OIT to zaburzenia funkcji wykonawczych, zaburzenie uwagi oraz długoterminowe upośledzenie pamięci. Problem SAE ujrzał światło dzienne, gdy zmniejszenie śmiertelności na OIT spowodowało większe zainteresowanie jakością życia pacjentów po wypisaniu z oddziału. Poprawa jakości opieki na OIT zwróciła również uwagę na śmiertelność długoterminową i możliwości przeżycia pacjentów poza oddziałami intensywnej opieki medycznej.

\section{PIŚMIENNICTWO}

1. Ebersoldt M, Sharshar T, Annane D. Sepsis-associated delirium. Intensive Care Med 2007;33:941-50.

2. Kumar G, Kumar N, Taneja A, Kaleekal T, Tarima S, McGinley E, et al. Milwaukee Initiative in Critical Care Outcomes Research (MICCOR) Group of Investigators. Nationwide trends of severe sepsis in the 21st century (2000-2007). Chest 2011;140(5):1223-31. doi: 10.1378/chest. 11-0352. 
3. Iwashyna TJ, Ely EW, Smith DM, Langa KM. Long-term cognitive impairment and functional disability among survivors of severe sepsis. JAMA 2010;304:1787-94.

4. Gofton TE, Young GB. Sepsis-associated encephalopathy. Nat Rev Neurol 2012;8(10):557-66. doi: 10.1038/nrneurol.2012.183.

5. Salluh JI, Soares M, Teles JM, Ceraso D, Raimondi N, Nava VS, et al. Delir ium Epidemiology in Critical Care Study Group. Delirium epidemiology in critical care (DECCA): an international study. Crit Care 2010;14(6):R210. doi: $10.1186 /$ cc9333

6. Zhang LN, Wang XT, Ai YH, Guo QL, Huang L, Liu ZY, et al. Epidemiological features and risk factors of sepsis-associated encephalopathy in inten sivecare unit patients: 2008-2011. Chin Med J (Engl) 2012;125:828-31.

7. Mikkelsen ME, Christie JD, Lanken PN, Biester RC, Thompson BT, Bellamy $\mathrm{SL}$, et al. The adult respiratory distress syndrome cognitive outcomes study: long-term neuropsychological function in survivors of acute lung injury. Am J Respir Crit Care Med 2012;185:1307-15.

8. Pandharipande PP, Girard TD, Jackson JC, Morandi A, Thompson JL, Pun BT, et al. BRAIN-ICU Study Investigators. Long-term cognitive impairment after critical illness. N Engl J Med 2013;369:1306-16. doi: 10.1056/ NEJMoa1301372.

9. Ehlenbach WJ, Hough CL, Crane PK, Haneuse SJ, Carson SS, Curtis JR, et al. Association between acute care and critical illness hospitalization and cognitive function in older adults. JAMA 2010;303:763-70.

10. Griffin WS. Neuroinflammatory cytokine signaling and Alzheimer's disease. N Engl J Med 2013;368:770-1.

11. Munster BC, Aronica E, Zwinderman AH, Eikelenboom P, Cunningham C, Rooij SE. Neuroinflammation in delirium: a postmortem case-control study. Rejuvenation Res 2011;14(6):615-22. doi: 10.1089/rej.2011.1185.

12. Murray C, Sanderson DJ, Barkus C, Deacon RM, Rawlins JN, Bannerman DM, et al. Systemic inflammation induces acute working memory deficits in the primed brain: relevance for delirium. Neurobiol Aging 2012;33:60316.e603.

13. Luitse MJ, van Asch CJ, Klijn CJ. Deep coma and diffuse white matter abnormalities caused by sepsis-associated encephalopathy. Lancet 2013;381:2222.

14. Gofton TE, Young GB. Sepsis-associated encephalopathy. Nat Rev Neurol 2012;8(10):557-66. doi:10.1038/nrneurol.2012.183.

15. Young GB, Bolton CF, Austin TW, Archibald YM, Gonder J, Wells GA. The encephalopathy associated with septic illness. Clin Invest Med 1990;13:297-304.

16. van den Boogaard M, Kox M, Quinn KL, van Achterberg T, van der Hoeven JG, Schoonhoven L, et al. Biomarkers associated with delirium in critically ill patients and their relation with long-term subjective cognitive dysfunction; indications for different pathways governing delirium in inflamed and noninflamed patients. Crit Care 2011;15:R297.

17. Nguyen DN, Spapen H, Su F, Schiettecatte J, Shi L, Hachimi-Idrissi S, et al. Elevated serum levels of S-100beta protein and neuron-specific enolase are associated with brain injury in patients with severe sepsis and septic shock. Crit Care Med 2006;34:1967-74.

18. Fioretto JR, Martin JG, Kurokawa CS, Carpi MF, Bonatto RC, Ricchetti SM, et al. Interleukin- 6 and procalcitonin in children with sepsis and septic shock. Cytokine 2008;43:160-4.

19. Field RH, Gossen A, Cunningham C. Prior pathology in the basal forebrain cholinergic system predisposes to inflammation-induced working memory deficits: reconciling inflammatory and cholinergic hypotheses of delirium. J Neurosci 2012;32:6288-94.

20. Martin BJ, Buth KJ, Arora RC, Baskett RJ. Delirium as a predictor of sepsis in post-coronary artery bypass grafting patients: a retrospective cohort study. Crit Care 2010;14:R171.

21. Girard TD, Jackson JC, Pandharipande PP, Pun BT, Thompson JL, Shintani $\mathrm{AK}$, et al. Delirium as a predictor of long-term cognitive impairment in survivors of critical illness. Crit Care Med 2010;38:1513-20.

22. Gunther ML, Morandi A, Krauskopf E, Pandharipande P, Girard TD, Jackson JC, et al. VISIONS Investigation, VISualizing Icu SurvivOrs Neuroradiological Sequelae. The association between brain volumes, delirium duration, and cognitive outcomes in intensive care unit survivors: the VISIONS cohort magnetic resonance imaging study. Crit Care Med 2012;40(7):2022-32. doi: 10.1097/CCM.0b013e318250acc0.

23. Boomer JS, To K, Chang KC, Takasu O, Osborne DF, Walton AH, et al. Immunosuppression in patients who die of sepsis and multiple organ failure. JAMA 2011;306:2594-605.

24. Hotchkiss RS, Coopersmith CM, McDunn JE, Ferguson TA. The sepsis seesaw: tilting toward immunosuppression. Nat Med 2009;15:496-7.

25. Woiciechowsky C, Schoning B, Daberkow N, Asche K, Stoltenburg G, Lanksch WR, et al. Brain-IL-1beta induces local inflammation but systemic anti-inflammatory response through stimulation of both hypothalamic-pituitary-adrenal axis and sympathetic nervous system. Brain Res 1999;816:563-71.

26. Sundar SK, Cierpial MA, Kilts C, Ritchie JC, Weiss JM. Brain IL-1-induced immunosuppression occurs through activation of both pituitary-adrenal axis and sympathetic nervous system by corticotropin-releasing factor. J Neurosci 1990;10:3701-6.

27. Dungan KM, Braithwaite SS, Preiser JC. Stress hyperglycaemia. Lancet 2009;373:1798-807.

28. Sharshar T, Blanchard A, Paillard M, Raphael JC, Gajdos P, Annane D. Circulating vasopressin levels in septic shock. Crit Care Med 2003;31: 1752-8.

29. Zhang X, Zhang G, Zhang H, Karin M, Bai H, Cai D. Hypothalamic IKKbeta/ NF-kappaB and ER stress link overnutrition to energy imbalance and obesity. Cell 2008;135:61-73.

30. Kavanagh BP, McCowen KC. Clinical practice. Glycemic control in the ICU. N Engl J Med 2010;363:2540-6.

31. Hotta N, Ichiyama T, Shiraishi M, Takekawa T, Matsubara T, Furukawa S. Nuclear factor-kappaB activation in peripheral blood mononuclear cells in children with sepsis. Crit Care Med 2007;35:2395-401.

32. Hoorn EJ, Betjes MG, Weigel J, Zietse R. Hypernatraemia in critically ill patients: too little water and too much salt. Nephrol Dial Transplant 2008;23:1562-8.

33. Singer M, Deutschman CS, Seymour CW, Shankar-Hari M, Djillali A, Bauer $M$, et al. The third international consensus definitions for sepsis and septic shock (Sepsis-3). JAMA 2016;315(8):801-10.

34. Dellinger RP, Levy MM, Rhodes A, Annane D, Gerlach H. Surviving sepsis campaign: international guidelines for management of severe sepsis and septic shock: 2012. Crit Care Med 2013;41(2):580-637.

35. Sakr Y, Rubatto Birri PN, Kotfis K, Nanchal R, Shah B, Kluge S, et al. Intensive Care Over Nations Investigators. Higher fluid balance increases the risk of death from sepsis: results from a large international audit. Crit Care Med 2017;45(3):386-94. doi: 10.1097/CCM.0000000000002189. 